\title{
Determination of Sensory and Quality Changes at Treated Sea Bass (Dicentrarchus labrax) During Cold-Storage
}

\author{
Yunus Alparslan*, Çiğdem Gürel, Cansu Metin, Hatice Hasanhocaoğlu and Taçnur Baygar
}

Mugla University Fisheries Faculty, Department of Seafood Processing Technology, 48000 Kotekli/MUGLA, Turkey

\begin{abstract}
In this study, it was aimed to point out the quality changes of fish flesh that had been stored in refrigerator $\left(4 \pm 1^{\circ} \mathrm{C}\right)$. Fish was separated in 4 treatments were whole-scaly, scales-gutted, and scales fillets. Samples were put in polystyrene boxes and covered with stretch film. The samples were sampled on days 0, 2. 4, 6, 8, 10 and 12. Protein, Lipid, Sensory, $\mathrm{pH}$, Total volatile base nitrogen (TVB-N), Trimethyl amine nitrogen (TMA-N) and Thiobarbituric acid (TBA) analysis were done during the storage. According to the chemical analysis results, experimental samples were under the upper limits of acceptability in terms of $\mathrm{pH}$, TMA- $\mathrm{N}$, TBA values at the end of the 12 days of storage in the refrigerator, while TVB-N values of whole-scaly sea bass exceeded. However, sensorially, scale-less-gutted and scale-less-filleted treatments exceeded the acceptability limit values after 8 days storage and so did the whole group after 10 days storage.
\end{abstract}

Keywords: Sea bass; Dicentrarchus labrax; Refrigerator storage; Sensory assessment; Chemical quality

\section{Introduction}

Seafood are rapidly deteriorating food so several preservation techniques are used for maintaining their nutritional components and delivering fresh to the consumer. The most commonly used is cooling technique and it is used commonly at the facilities and especially at the households [1].

Sea bass (Dicentrarchus labrax L. 1758) is found in our waters naturally and consumed well in the World as the Turkey due to flavor of its meat. Besides it is preferred because of its durability of different conditions and culturing successfully in controlled environment [2]. The meat of fish effects from physical and environmental factors rapidly from harvesting point, because of its sensitivity to degradation. In this situation after harvesting, it must be consumed in a short time or if it is not possible it should be conserved in various ways and be protected. The processing technologies which had developed for this aim show diversity and the aim of these technologies to maintain the existing quality as much as possible and to protect consuming of the fish for a long time [3].

Fish are affected by the quality loss rapidly when the unsuitable storage conditions, unconscious transportation rules, wrong processing methods and insufficient cold chain implementations are used. These quality losses occur more especially at the restaurants and the households. The fish that launched and bought are put up for sale as whole fish, gutted or filleted. The fish that bought in these ways, if they are not consumed immediately are kept in a refrigerator $\left(+4^{\circ} \mathrm{C}\right)$ and forgotten. The wrong treatments and storage conditions which applied at the households cause spoilage in a short time. The aim of this study was to determine sensory and chemical quality changes which occur in the fresh sea bass (whole-scaly, scale-less-gutted and scale-less-filleted) when stored at refrigerator conditions.

\section{Material and Methods}

\section{Raw material}

A total of $70 \mathrm{~kg}$ of farmed sea bass (Dicentrarchus labrax, L. 1758) with individual, portion size fish weighing 300-350g was used as an investigation material in this study. (Kilic Seafood Product Holding,
Milas/Mugla/TURKEY). The fish that were taken as scaly-whole, scale-less-gutted and scale-less-filleted were brought to the laboratory in polystyrene boxes under cold conditions $\left(0-2^{\circ} \mathrm{C}\right)$ in 2 hours. The three groups of fish were divided as scaly-whole, scale-less-gutted and scale-less-filleted by wrapping with stretch films and putting strafor plates and stored in refrigerator $\left(+4 \pm 1^{\circ} \mathrm{C}\right)$. Protein, Lipid, Sensory, $\mathrm{pH}$, TVB-N, TMA-N, TBA analysis were applied for fish samples of each group at the $0,2,4,6,8,10,12^{\text {th }}$ days of the storage. The analyses were performed three times. The study was repeated two times. The overall average results were given.

\section{Proximate analysis}

The fish samples were analysed in triplicate for proximate composition: lipid content of sea bass by the Bligh and Dyer [4] method, total crude protein by Kjeldhal method [5].

\section{Sensory analysis}

Sensory analyses were conducted according to the Aubourg [6] by 6 panelists. According to the scale, points of 3-4 were evaluated as "best quality", points between 2 to 3 were evaluated as "good quality", points between 1 to 2 were evaluated as "moderate quality" and points lower than 1 were evaluated as "not acceptable". The scores of the panellists were averaged.

\section{Chemical analysis}

The $\mathrm{pH}$ values were recorded by using a InoLab model digital $\mathrm{pH}$ meter (InoLab, WTW, Germany) after homogenization of each $10 \mathrm{~g}$

*Corresponding author: Yunus Alparslan, Mugla University Fisheries Faculty Department of Seafood Processing Technology, 48000 Kotekli/MUGLA, Turkey, E-mail: yunusalparslan@mu.edu.tr

Received July 06, 2012; Accepted September 04, 2012; Published September 12,2012

Citation: Alparslan Y, Gürel Ç, Metin C, Hasanhocaoğlu H, Baygar T (2012) Determination of Sensory and Quality Changes at Treated Sea Bass (Dicentrarchus labrax) During Cold-Storage. J Food Process Technol 3:183. doi:10.4172/21577110.1000183

Copyright: (c) 2012 Alparslan Y, et al. This is an open-access article distributed under the terms of the Creative Commons Attribution License, which permits unrestricted use, distribution, and reproduction in any medium, provided the original author and source are credited. 
fish muscle sample in $100 \mathrm{ml}$ distilled water. The vapour distillation method was used to estimate Total Volatile Bases Nitrogen (TVB-N, $\mathrm{mg} \mathrm{N} \mathrm{100-1} \mathrm{g)} \mathrm{and} \mathrm{expressed} \mathrm{as} \mathrm{milligrams} \mathrm{of} \mathrm{TVB-N} \mathrm{for} 100 \mathrm{~g}$ fish muscle [7]. Thiobarbituric acid (TBA) reactive substances were determined according to Tarladgis et al. [8], to evaluate the oxidation stability during chilled storage and the results expressed as TBA index, milligrams of malonaldehyde per $\mathrm{kg}$ flesh. The trimethylamine nitrogen (TMA-N) content of sample was determined according to the method of Schormüller. [9] and expressed as mg TMA-N per $100 \mathrm{~g}$ fish muscle.

\section{Statistical analysis}

SPSS 14 for Windows was used and Statistical differences between the different sets of data (freshness results, proximate composition analysis between days, changes of biochemical measurements) should be determined by performing analysis of variance (one-way ANOVA), followed by a least significance difference test at $95 \%$ confidence level.

\section{Results and Discussions}

\section{Proximate analysis results}

Crude protein: Crude protein analysis results are shown in Figure 1. At the beginning of the storage period, the crude protein values for fresh sea bass were determined as $19.43 \pm 0.55$. At the end of the 12 days of storage period, crude protein values decreased to $18.32 \pm 0.24 \%$, $18.23 \pm 0.87 \%$ and $18.47 \pm 0.60 \%$, for scaly-whole, scale-less-gutted and scale-less-filleted sea bass, respectively. As protein results, the decrease was determined at all fish groups depends on the storage duration. There were no statistically significant difference ( $p>0.05)$ among the fish groups in terms of the protein values. Dinçer et al. [10] determined $\%$ crude protein value of cultured fresh sea bass in Aegean Sea as $19.38 \pm 0.47 \%$. These value show similarity with our values.

Crude lipid: Crude lipid analysis results of the fish groups are shown in Figure 2. At the beginning of the storage period, the percent crude fat value for fresh sea bass was determined as $8.36 \pm 0.49$. At the end of the 12 days of storage period, percent crude fat values decreased to $7.88 \pm 0.14 \%, 7.52 \pm 0.16 \%$ and $7.48 \pm 0.42 \%$, for scaly-whole, scaleless-gutted and scale-less-filleted sea bass, respectively. As a result of the lipid \% analysis depending on the storage duration, a decrease was determined. The changes as a result of fragmentation of the lipids depend on a long storage time. At the end of the storage the lowest lipid content was seen at scale-less fillets and also the highest lipid content was seen at whole-scaly and scale-less-gutted samples. The difference between the untreated whole-scaly sea bass and scale-less-filleted samples was determined significant $(p<0.05)$, the difference between the other groups was determined insignificant $(p>0.05)$. Dinçer et al. [10] determined the $\%$ crude lipid value of the sea bass which is cultured in Aegean Sea as $7.84 \pm 0.20 \%$ in their study. Kyrana and Lougovis [11], also determined the lipid content of the sea bass meat as $3.90 \%$. Although the values of the sea bass of our study show similarity with the values that Dinçer et al. [10], obtained in their study, they were different from the values that Kyrana and Lougovis [11] obtained. It was thought that this was because the sea bass which had been used in the study of Kyrana and Lougovis [11] was caught from the wild. The chemical composition of the same species of marine fish shows differences among each other depends on the nutrition, life conditions, catching season, seasonal and sexual

\section{Sensory analysis results}

Sensory analysis results of fish groups are shown in Figure 3. At the beginning of the storage period, the sensory analysis values by the panelist for scaly-whole, scale-less-gutted and scale-less-filleted sea bass were determined as 3.8, 3.7 and 3.6, respectively. According to sensory analysis results it was determined that at the end of the 12 days of storage period scale-less-gutted and scale-less-filleted fish groups exceeded the consumption limit after 8 days $(0.6)$ and this period was 10 days (0.7) for whole fish group. Liquid loss in eyes, color changes in grills, drying on the skin, softness in meat and odour changes among the groups were effective for sensory values. It was indicated that there is a statistical difference $(\mathrm{p}<0.05)$ between the untreated whole-scaly fish group, scale-less-gutted and scale-less-filleted group and this difference is insignificant $(p>0.05)$ between the scale-less-gutted and scale-less-filleted groups. Cakli et al. [13] indicated that in the study of

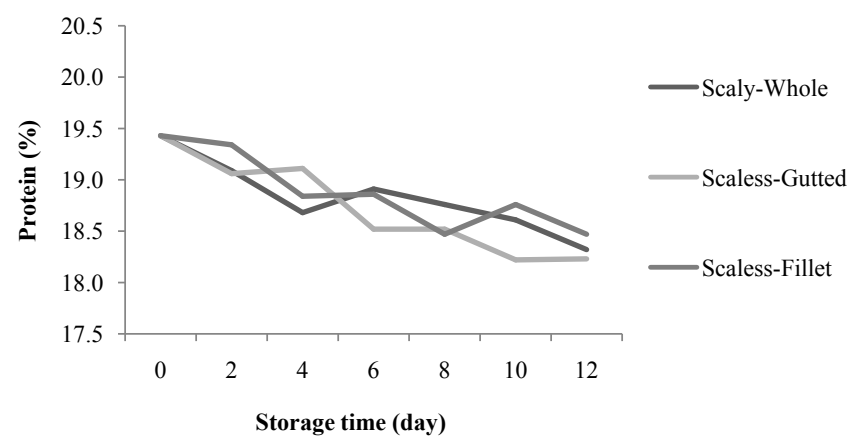

Figure 1: The avarage results of the crude protein analysis of the seabass stored in the refrigerator $\left(+4 \pm 1^{\circ} \mathrm{C}\right)$.

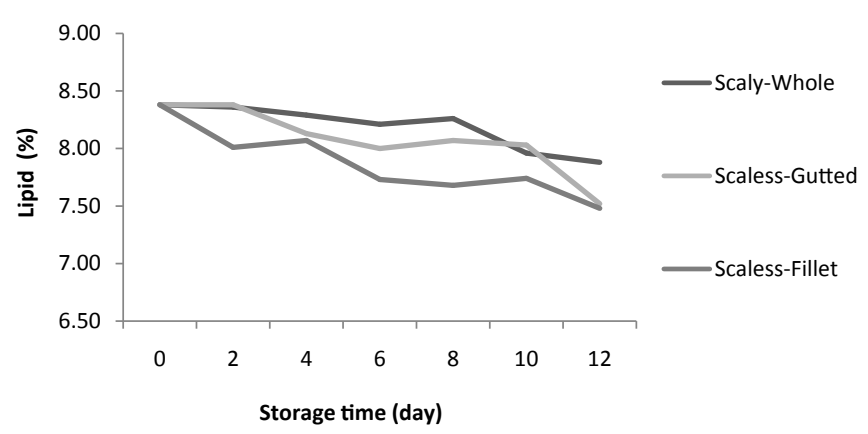

Figure 2: The avarage results of the crude lipid analysis of seabass stored in the refrigerator $\left(+4 \pm 1^{\circ} \mathrm{C}\right)$.

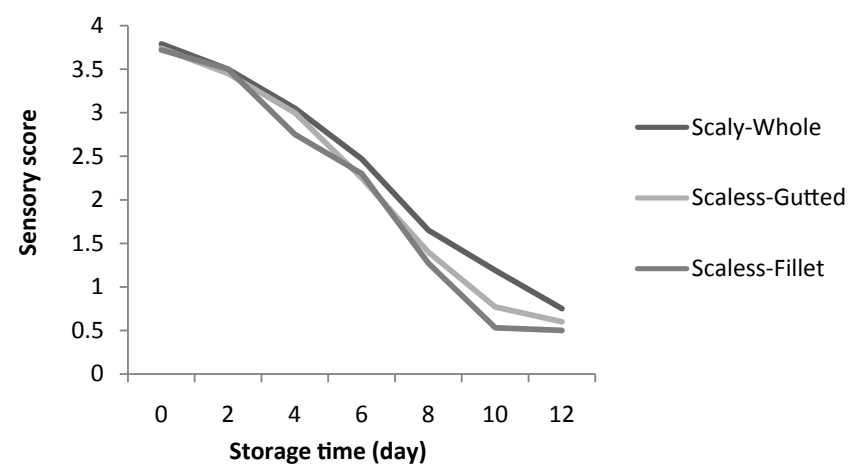

Figure 3: The avarage results of the sensory analysis of seabass stored in refrigerator $\left(+4 \pm 1^{\circ} \mathrm{C}\right)$ 
using liquid ice on the cultured sea bass at $+4^{\circ} \mathrm{C}$, sensory, microbiologic and chemical assessments were done and as sensory analysis all of the groups didn't exceed the consumption limit. According to Kilınc et al. [14] the cultured sea bass which had been stored at the $+4^{\circ} \mathrm{C}$ quality effects were compared after liquid ice and flake ice pre-treatment at the end of the 15 days of storage it was determined that as sensory analysis the sea bass were in consumption limit until the 13th day. The observed organoleptic shelf-life of sea bass was found to be 16 days in ice, 4 days in boxes without ice, 8 days in aluminium foil and 8 days in cling film [15]. Poli et al. [16] reported that the limit of acceptability for ungutted sea bass was 10 days. The results which found in our study shows parallel.

\section{Chemical analysis results}

pH analysis results: $\mathrm{pH}$ analysis results of the fish groups are shown in Figure 4. At the beginning of the storage period, the $\mathrm{pH}$ values for fresh sea bass were determined as $6.43 \pm 0.07$. At the end of the 12 days of storage period, $\mathrm{pH}$ values were determined as $6.72 \pm 0.01,6.74 \pm 0.03$ and $6.77 \pm 0.11$, for scaly-whole, scale-less-gutted and scale-less-filleted sea bass, respectively. According to the results of study there is an increase at $\mathrm{pH}$ content because of nitrogenous substances that fish include depends on storage duration. At the beginning of the storage a decrease that occurs at each of the three group's $\mathrm{pH}$ value is a result of lactic acid that releases during rigor mortis. The lowest $\mathrm{pH}$ value was seen at whole fish samples. The significant difference between wholescaly fish group and scaleless-filleted was determined $(\mathrm{p}<0.05)$, also the difference between scale-less-gutted and scale-less-filleted groups was determined insignificant ( $\mathrm{p}>0.05)$. Erkan and Ozden [17] reported that $\mathrm{pH}$ value ranged from 6.46 to 6.64 for whole ungutted and from 6.55 to 6.67 , for gutted sea bass respectively, during the 13 day storage period. Values of $\mathrm{pH}$ were not significantly different $(\mathrm{p}>0.05)$ during the entire period of storage. According to the literature, the $\mathrm{pH}$ is about 6.0-6.5 for fresh fish, and it increases during storage. The limit of acceptability is usually 6.8-7.0 [12]. However, post-mortem $\mathrm{pH}$ can vary considerably depending on the season, the species, and other factors [18].

TVB-N analysis result: TVB-N results of the fish groups are shown in Figure 5. TVB-N content of fish is indicator of the raw material freshness [19]. At the beginning of the storage period, the TVB-N values for fresh sea bass were determined as $18.87 \pm 1.62 \mathrm{mg} / 100 \mathrm{~g}$. At the end of the 12 days of storage period, TVB-N values increased to $28,09 \pm 1,3032,85 \pm 2,92$ and $39,49 \pm 2,75 \mathrm{mg} / 100 \mathrm{~g}$, for scaly-whole, scale-less-gutted and scale-less-filleted sea bass, respectively. According to TVB-N assessment release of nitrogenous substances including protein and as a result of the other quality losses and increase was seen at TVB-N value of three groups during storage. At the end of the storage the highest TVB-N value was seen at the scale-less fillets and it was determined that the TVB-N value of this group was exceed the consumption limit after the 10th day. The statistical difference among the groups was determined $(p<0.05)$. Erkan et al. [17] indicated that in the study of the effects of the storage in ice $\left(+4^{\circ} \mathrm{C}\right)$ to the whole and gutted sea bass' quality and shelf life at the end of the 12 days of storage, TVB-N values were in the limiting value of consumable $(25 \mathrm{mg} / 100 \mathrm{~g})$. Ozogul et al. [15] reported that effects of aluminium foil and cling film on microbiological, chemical and sensory changes in wild sea bass (Dicentrarchus labrax) stored at chill temperature $\left(4^{\circ} \mathrm{C}\right)$ were studied. A quality assessment of wild sea bass stored in ice, in boxes without ice, wrapped in aluminium foil and wrapped in cling film at $4^{\circ} \mathrm{C}$ was performed by monitoring sensory quality, nucleotide breakdown products, TVB-N, and total viable counts (TVCs). Taliadourou et al. [20] reported that TVB-N values showed a slight increase for whole

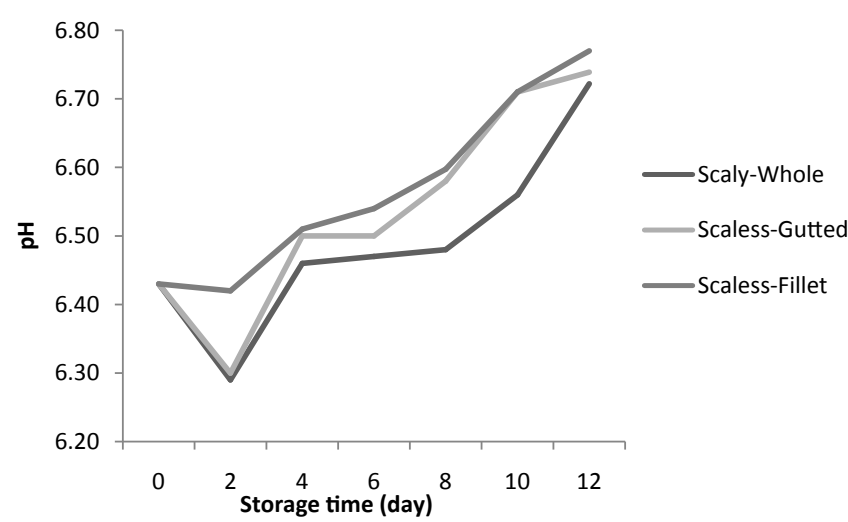

Figure 4: The avarage results of the $\mathrm{pH}$ analysis of seabass stored in the refrigerator $\left(+4 \pm 1^{\circ} \mathrm{C}\right)$.

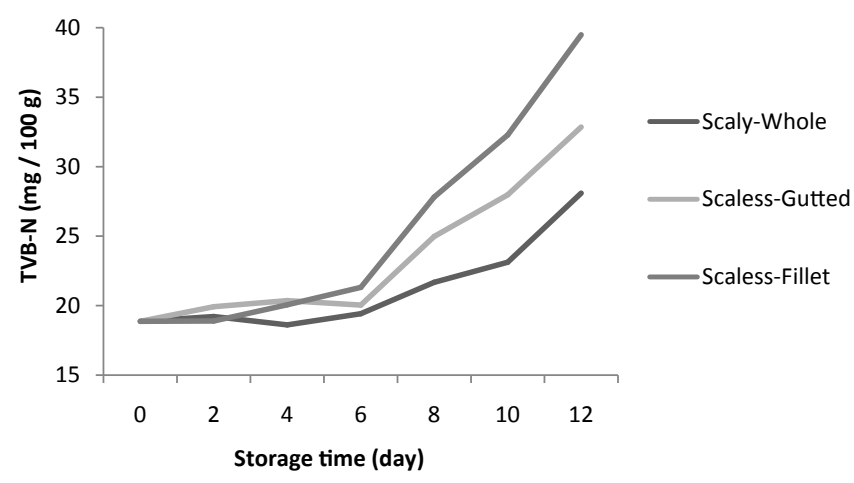

Figure 5: The avarage results of the TVB-N analysis of the seabass stored in the refrigerator. $\left(+4 \pm 1^{\circ} \mathrm{C}\right)$.

ungutted sea bass during storage, reaching a value of $26.77 \mathrm{mg} \mathrm{N}$ per $100 \mathrm{~g}$ muscle (day 13), whereas for filleted fish a corresponding value of $26.88 \mathrm{mg} \mathrm{N}$ per $100 \mathrm{~g}$ muscle was recorded (day 9). Papadopoulos et al. [21] also found that content of TVB-N ranged from 25.7 to $27.7 \mathrm{mg} \mathrm{N} / 100 \mathrm{~g}$ flesh for ungutted and from 27.2 to $36 \mathrm{mg} \mathrm{N} / 100 \mathrm{~g}$ flesh for gutted sea bass during the 16 days of storage in ice. TVB-N values showed significant fluctuation for all fish samples as a function of storage period indicating that TVB-N is a poor indicator of fish freshness, as also proposed by Tejada and Huidobro [22]. A TVB-N level of about $25 \mathrm{mg} / 100 \mathrm{~g}$ flesh could be regarded as the limit of acceptability for iced European sea bass [11]

TMA-N analysis results: TMA-N results of the fish groups are shown in Figure 6. TMA is produced by the decomposition of TMA-O caused by bacterial spoilage and enzymatic activity [13]. At the beginning of the storage period, the TMA-N values for fresh sea bass were determined as $3.19 \pm 0.03 \mathrm{mg} / 100 \mathrm{~g}$. At the end of the 12 days of storage period, TMA-N values increased to $4,41 \pm 0,07,6,77 \pm 0,15$ and $7,29 \pm 0,24 \mathrm{mg} / 100 \mathrm{~g}$, for scaly-whole, scale-less-gutted and scaleless-filleted sea bass, respectively. There was not a change until the day 6 at the TMA-N value, after the day 8 it was found that TMA-N value increased slowly. At the end of the storage the highest TMA-N content was found at the scale-less fillets, and the lowest value was at the scale-less-gutted samples. Statistical difference $(p<0.05)$ was determined among the fish groups for TMA-N values. TMA values of whole ungutted sea bass increased very slowly, whereas significantly 
Citation: Alparslan Y, Gürel Ç, Metin C, Hasanhocaoğlu H, Baygar T (2012) Determination of Sensory and Quality Changes at Treated Sea Bass (Dicentrarchus labrax) During Cold-Storage. J Food Process Technol 3:183. doi:10.4172/2157-7110.1000183

higher values were obtained for filleted samples, with respective values of 0.253 and $1.515 \mathrm{mg} \mathrm{N}$ per $100 \mathrm{~g}$ muscle being reached at the end of their shelf-life (days 13 and 9, respectively) [20]. Erkan and Ozden [17] reported that trimethylamine (TMA-N) values of whole and gutted sea bass increased very slowly, reaching final values of 3.94 and, 3.38 $\mathrm{mg} / 100 \mathrm{~g}$, respectively (day 13 ).

TBA analysis results: TBA analysis results of the fish groups are shown in Figure 7. The TBA values are a widely used indicator for the assessment of the degree of lipid oxidation [13]. At the beginning of the storage period, the TBA values for fresh sea bass were determined as $0.42 \pm 0,03 \mathrm{mg}$ malonaldehyde $/ \mathrm{kg}$. At the end of the storage period of 12 days, TBA values were determined as $0.55 \pm 0.03,0.64 \pm 0.14,0.57 \pm 0.02$ $\mathrm{mg}$ malonaldehyde $/ \mathrm{kg}$, for scaly-whole, scale-less-gutted and scale-lessfilleted sea bass, respectively. The obtained results were considerably lower than the accepted limit for human consummation of 5-8 mgMA/ $\mathrm{kg}$. Although fish has high content of lipids it was thought that because of the treatment of cold conditions and treating hygienic processes using the packaging material stretch film cuts the contact with oxygen. The untreated whole-scaly fish and scale-less-gutted fish group and also the scale-less-filleted group have a statistical difference $(\mathrm{p}<0.05)$ among each other. The difference was insignificant $(p>0.05)$ between the whole-scaly fish and scale-less-filleted fish group TBA values increased slowly for whole ungutted and filleted sea bass samples throughout the entire storage period, reaching final values of 4.48 (day 13) and 13.84 (day 9) mg malonaldehyde/kgrespectively Taliadourou et al. [20], Cakli et al. [13] reported that at the end of the storage period of 14 days, TBA values of ungutted sea bass were determined as $2.66 \pm 0.06 \mathrm{mg}$

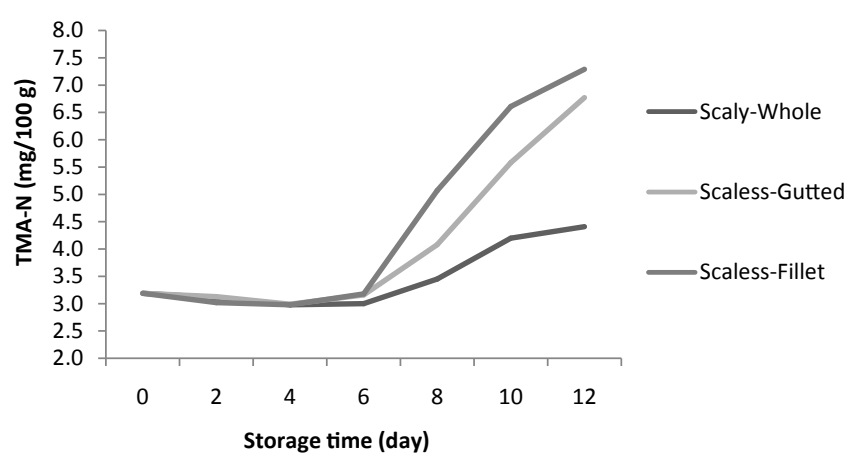

Figure 6: The avarage results of the TMA-N analysis of seabass stored in refrigerator $\left(+4 \pm 1^{\circ} \mathrm{C}\right)$.

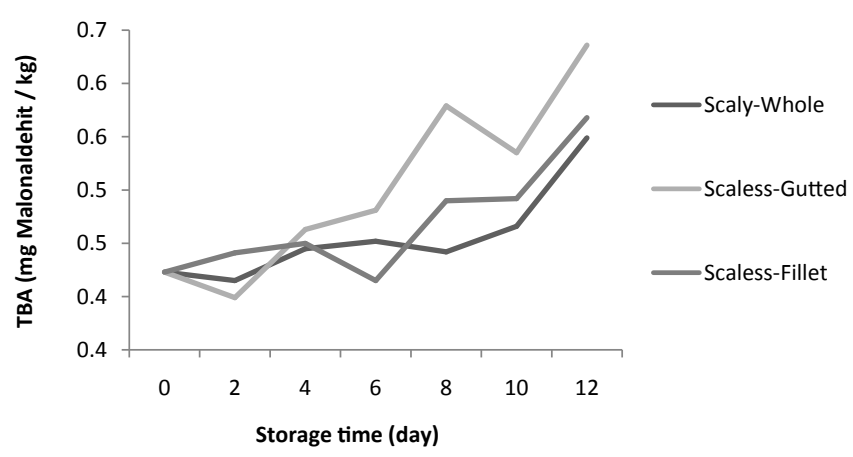

Figure 7: The avarage results of the TBA analysis of seabass stored in refrigerator $\left(+4 \pm 1^{\circ} \mathrm{C}\right)$. malonaldehyde $/ \mathrm{kg}$. In our study TBA value that occurs because of lipid oxidation was found too lower from these values. This was thought because of low crude lipids at fresh sea bass at the beginning.

\section{Conclusions}

The aim of this study was to determine sensory and chemical quality changes which occur at sea bass (whole-scaly, scale-less-gutted and scale-less-filleted) that had been stored in refrigerator conditions. As a result of the study it was determined that all of the groups were in consumption limit in terms of $\mathrm{pH}$, TBA, TMA-N values at 12 days of refrigerator storage $\left(+4 \pm 1^{\circ} \mathrm{C}\right)$, however TVB-N values exceeded the consuming limit. In terms of sensory analysis scale-less-gutted and scale-less-filleted sea bass after 8th day, scaly-whole sea bass after 10th day exceeded the acceptable consumption limit.

\section{References}

1. Varlık C, Ozden O, Erkan N, Alakavuk D (2007) Basic quality control for fishery products. Istanbul University, Faculty of Fisheries Department of Processing Technology.

2. Alparslan Y, Baygar T (2009) Place sea bass in Turkey and in the world, the importance and the market situation. Republic of Turkey Journal of Vocational School Anadolu Bil 13: 31-40.

3. Patır B, Duman M (2006) Smoked mirror carp (Cyprinus carpio) fillets during storage consisting of determination of the physico-chemical and microbiological changes. Firat University Journal of Science and Engineering 18: 189-195.

4. Bligh EG, Dyer WJ (1959) A rapid methods of total lipid extraction and purification. Canadian Journal of Biochemistry and Physiology 37: 911-917.

5. AOAC (1984) Officials methods of analysis. Association of official analytical chemists. Washington D.C., USA

6. Aubourg SP (2001) Chilled storage of horse mackarel. Journal of American Oi Chemists Society 78: 857-862.

7. Antonacopoulos N, Vyncke W (1989) Determination of volatile basic nitrogen in fish: A third collaborative study by the West European Fish Technologists Association (WEFTA). Zeitschrift Fur Lebensmittel Untersuchung UndForschung A 189: 309-316

8. Tarladgis BG, Watts BM, Yonathan M (1960) A distillation method for the quantitative determination of malonaldehyde in rancid foods. Journal of American Oil Chemists Society 37: 44-48.

9. Schormüller J (1968) Handbuch der Lebensmittel Chemie. Band III/2 Teil. Tierische Lebensmittel Eier, Fleisch, Buttermilch, Springer Verlag, Berlin, Heidelberg, New York: 1482-1537.

10. Dinçer TM, Cadun A, Gamsız K (2009) Comparison of quality parameters of the Aegean Sea and the Black Sea cultured sea bass. Istanbul University Journal of Fisheries 24: 25-37.

11. Kyrana VR, Lougovois VP (2002) Sensory, chemical and microbiological assessment of farm-raised European sea bass (Dicentrarchus labrax) stored in melting ice. International Journal of Food Sciences and Technology 37 319-328.

12. Ludorff W, Meyer V (1973) Fish and fish products. Verlag Paul Parey: Hamburg, Berlin, $308 \mathrm{pp}$

13. Cakli S, Kilinc B, Cadun A, Dincer T, Tolasa S (2006) Effects of gutting and ungutting on microbiological, chemical, and sensory properties of aquacultured sea bream (Sparus aurata) and sea bass (Dicentrarchus labrax) stored in ice. Crit Rev Food Sci Nutr 46: 519-527.

14. Kilinc B, Cakli S, Cadun A, Dincer T, Tolasa S (2007) Comparison of effects of slurry ice and flake ice pretreatments on the quality of aquacultured sea bream (Sparus aurata) and sea bass (Dicentrarchus labrax) stored at $4^{\circ} \mathrm{C}$. Food Chemistry 104: 1611-1617.

15. Ozogul F, Gokbulut C, Ozyurt G, Ozogul Y, Dural M (2005) Quality assessment of gutted wild sea bass (Dicentrarchus Labrax) stored in ice, cling film and aluminium foil. European Food Research and Technology 220: 292-298.

16. Poli MB, Parisi G, Zambacavallo G, Mecatti M, Lupi P, et al. (2001) Quality 
Citation: Alparslan Y, Gürel Ç, Metin C, Hasanhocaoğlu H, Baygar T (2012) Determination of Sensory and Quality Changes at Treated Sea Bass (Dicentrarchus labrax) During Cold-Storage. J Food Process Technol 3:183. doi:10.4172/2157-7110.1000183

Page 5 of 5

outline of European sea bass (Dicentrarchus labrax) reared in Italy: shelf life, edible yield, nutritional and dietetic traits. Aquaculture 202: 303-313.

17. Erkan N, Ozden O (2006) Gutted and un-gutted sea bass (Dicentrarchus labrax) stored in Ice: Influence on fish quality and shelf-life. International Journal of Food Properties 9: 331-34.

18. Simeonidou S, Govaris A, Vareltzis K (1998) Quality assessment of seven Mediterranean fish during storage on ice. Food Research International 30 479-484.

19. De Koning AJ (2001) Quantitative quality tests for fish meal. An investigation of the quality of South African fish meals and the validity of a number of chemical quality indices. International Journal of Food Properties 5: 495-507.
20. Taliadourou D, Papadopoulos V, Domvridou E, Savvaidis IN, Kontominas MG (2003) Microbiological, chemical and sensory changes of whole and filleted Mediterranean aquacultured sea bass (Dicentrarchus labrax) stored in ice. Journal of the Science of Food and Agriculture 83: 1373-1379.

21. Papadopoulos V, Chouliara I, Badeka A, Savvaidis IN, Kontominas MG (2003) Effect of gutting on microbiological, chemical, and sensory properties, of aquacultured sea bass (Dicentrarchus labrax) stored in ice. Food Microbiology 20 414-420.

22. Tejada M, Huidobro A (2002) Quality of farmed gilthead sea bream (Sparus aurata) during ice storage related to the slaughter method and gutting European Food Research and Technology 215: 1-7. 